\title{
IMPACT OF A USED STABILISER ON THE CALIFORNIA BEARING RATIO OF THE CLAYEY-SANDY SILT
}

\author{
Katarzyna Kamińska' , Mariusz Cholewa' ${ }^{1}$ Klaudia Moskwik' \\ 1 University of Agriculture in Cracow, Al. Mickiewicza 24/28, 30-059 Kraków, Poland, e-mail: kasiadzierwa@ \\ interia.pl, m.cholewa@ur.krakow.pl
}

Received: 2016.09 .18

Accepted: 2016.10.23

Published: 2017.01.01

\begin{abstract}
The paper aimed at the determination of the California Bearing Ratio of a stabilised and unstabilised fine-grained mineral soil. A clayey-sandy silt with the addition of 3 , 6 and $10 \%$ of road stabilisers Solidex and Solidex A was used for the tests. The tests were carried out in the press Tritech 50 at the loading of 22 and $44 \mathrm{~N}$. The stabilised samples were subjected to 7-days treatment, whereas unstabilised 4-days treatment. Stabilization with the applied road binders brought positive effects, there occurred a significant improvement in the mechanical properties of the clayey-sandy silt. The better binder, which significantly increased the value of the CBR ratio, was Solidex A. The use of hydraulic binders is of a great importance in road building, because their addition improves the mechanical properties of weaker mineral soils.
\end{abstract}

Keywords: stabiliser, California Bearing Ratio, clayey-sandy silt

\section{INTRODUCTION}

A well developed and modern road infrastructure is a condition of a proper economic development of the country [GDDKiA 2015]. To meet the needs of the market and strong competition, the road network, especially motorways and express roads, require considerable financial outlays for development and repairs that influence safety and driving comfort. There is a rapid increase in the number of vehicles in Poland, consequently the challenge for the future years will be to ensure connections between major agglomerations and places where there is a connection with other forms of transport, like harbours and airports [Attachment to the Resolution... 2015].

Technical condition of the pavement has a significant influence on the increase in driving safety [Attachment to the Resolution... 2015]. The quality of the pavement construction depends on the type of the soil subbase [GDDKiA 2014]. The soil subbase is a lower layer of the earthen road embankment and it can be strengthened by forming an improved layer on its top surface [Wiłun 2000].
The improved layer of the subbase increases bearing capacity of the ground, influences proper forming and compaction of the higher construction layers and it also strengthens the pavement itself, so there is no frost heaves. In order to improve the parameters of heave soils, different binders like lime, cement, fly ash and other road stabilisers (natural and anthropogenic) are used [GDDKiA 2014].

In order to evaluate the quality of the subbase and its usefulness in road construction, physical and mechanical properties of the soil should be determined; one of the most important parameters is the California bearing ratio [Regulation of the Minister of Transport and the Maritime Economy on March $\left.2^{\text {nd }} 1999\right]$. This ratio is determined considering traffic load during dimensioning the thickness of construction layers in flexible pavements [Szpikowski 2006].

\section{MATERIALS AND METHODS}

The purpose of this research was to determine the California bearing ratio of a fine-grained min- 
eral soil and its mixtures with the addition of road stabilisers. Based on granulation of the tested soil, taken from Wrocławska Street in Cracow, was classified as clayey-sandy silt (Table 1) [PNEN ISO 14688-2]. Two mineral road binders Solitex and Solitex A - were used in the amount of 3.6 and $10 \%$, in relation to dry mass of the soil [PN-S-96012:1997].

Silt and sand fractions dominated in the soil their content was adequately 46 and $46.6 \%$; there was rather small clay fraction content $(7.2 \%)$ and trace amount of gravel fraction (Table 1). Based on the uniformity coefficient the silt was classified as well grained soil $(\mathrm{Cu}>15)$. Whereas because of the values of plastic and liquid limits the state of the soil was plastic [Wiłun 2000, Myślińska 1998]. Optimal moisture content, determined in Proctor's apparatus, was $10.2 \%$ and the maximum dry density $\mathrm{p}_{\mathrm{ds}}$ was $2.02 \mathrm{~g} \cdot \mathrm{cm}^{-3}$.

The values of passive capillary, sand equivalent and the content of grains below 0.075 and $0.02 \mathrm{~m}$ classify silt as a very heave soil [PN-S-02205:1998].

In road construction mineral binders such as Solitex can be used, among other things, for strengthening the subbase of the road pavement or improving soils in embankments, according to the requirements in [PN-S-96012:1997, PN-S02205:1998, Technical specification 2013].

Solitex stabilisers contain binding materials based on cement or hydrated lime, lime and siliceous fly ashes from coal combustion and mineral components [Material safety data sheet 2014].

The tests were carried out on cylindrical samples $17.5 \mathrm{~cm}$ high and $15.0 \mathrm{~cm}$ in diameter, which were formed in Proctor's apparatus using standard compaction energy and so-called CBR moisture content (Table 3), which is lower than optimal moisture content and equals $99 \%$ of maximum dry density [PN-S-02205: 1998].

CBR tests were carried out in Tritech 50 Press, with the load of 22 and $44 \mathrm{~N}$, using a plunger that was $5 \mathrm{~cm}$ in diameter (Fig. 1). After the unstabilised samples (clayey-sandy silt without any binders) were formed they were immersed in water for 4 days. In case of the stabilized samples there were two methods of 7-day curing. In the first series once the samples were formed they were kept at room temperature for 3 days and then immersed in water for 4 days. In the second series for the first 3 days the samples were also kept at room temperature, but for the next 4 days they were subjected to freeze-thaw cycles (Table 2).
One cycle is 8 -hour freezing at $-23^{\circ} \mathrm{C}$ and 16 hour thawing in water at room temperature.

The bearing ratio was calculated using the following formula [Pisarczyk 2014]:

$$
\mathrm{CBR}=\frac{\mathrm{P}}{\mathrm{Pp}} \cdot 100[\%]
$$

where: $p$ - pressure required to penetrate soil with a plunger of $20 \mathrm{~cm}^{2}$ area to a depth of $2.5 \mathrm{~mm}$ or $5.0 \mathrm{~mm}$ using constant velocity of $1.25 \mathrm{~mm} \cdot \mathrm{min}^{-1}$, [MPa]

$p_{p}$ - comparative pressure that equals 7 $\mathrm{MN} \cdot \mathrm{m}^{-2}$ when the plunger is at a depth of $2.5 \mathrm{~mm}$ and $10 \mathrm{MN} \cdot \mathrm{m}^{-2}$ when it is at $5.0 \mathrm{~mm}$

Table 1. Physical properties of the clayey-sandy silt

\begin{tabular}{|c|c|c|c|}
\hline Soil parameters & Symbol & Unit & Value \\
\hline Fraction content: & & & \\
\hline - gravel $2-63 \mathrm{~mm}$ & $\mathrm{Gr}$ & \multirow{4}{*}{$\%$} & 0.2 \\
\hline - sand $0.063-2 \mathrm{~mm}$ & Sa & & 46.0 \\
\hline - silt $0.002-0.063 \mathrm{~mm}$ & $\mathrm{Si}$ & & 46.6 \\
\hline - clay $<0.002 \mathrm{~mm}$ & $\mathrm{Cl}$ & & 7.2 \\
\hline $\begin{array}{l}\text { Name according to [PN- } \\
\text { EN ISO 14688-2] }\end{array}$ & saclSi & - & $\begin{array}{l}\text { clayey- } \\
\text { sandy silt }\end{array}$ \\
\hline Uniformity coefficient & $\mathrm{Cu}$ & - & 37 \\
\hline Specific density & $p_{s}$ & $\mathrm{~g} \cdot \mathrm{cm}^{-3}$ & 2.67 \\
\hline Maximum dry density & $p_{d s}$ & $\mathrm{~g} \cdot \mathrm{cm}^{-3}$ & 2.02 \\
\hline Optimal moisture content & OMC & \multirow[b]{2}{*}{$\%$} & 10.2 \\
\hline Sand equivalent & SE & & 11.1 \\
\hline Passive capillary & - & $\mathrm{m}$ & 1.34 \\
\hline Plastic limit & $\mathrm{PL}$ & \multirow{2}{*}{$\%$} & 11.2 \\
\hline Liquid limit & LL & & 19.8 \\
\hline
\end{tabular}

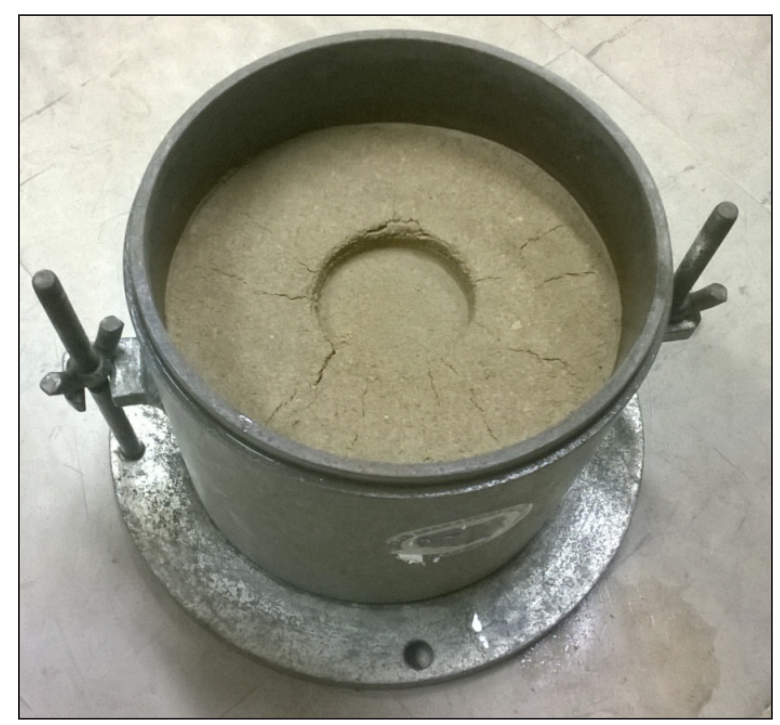

Figure 1. Sample after plunger penetration (laboratory of the Department of Hydraulic Engineering and Geotechnics) 
Table 2. Curing of samples before the bearing ratio test

\begin{tabular}{|c|c|c|c|}
\hline \multirow[b]{2}{*}{ Soil } & \multirow{2}{*}{$\begin{array}{c}\text { Stabiliser } \\
\text { addition } \\
\text { [\%] }\end{array}$} & \multicolumn{2}{|c|}{ Curing of samples } \\
\hline & & $\begin{array}{l}\text { Time } \\
\text { [days] }\end{array}$ & Method of curing \\
\hline $\begin{array}{c}\text { Clayey-sandy } \\
\text { silt }\end{array}$ & - & 4 & $\begin{array}{c}4 \text { days fully } \\
\text { immersed in water }\end{array}$ \\
\hline \multicolumn{4}{|c|}{$\left.\right|^{\text {st }}$ series } \\
\hline \multirow{3}{*}{$\begin{array}{l}\text { Mixtures with : } \\
\text { - Solitex } \\
\text { - Solitex A }\end{array}$} & 3 & \multirow{3}{*}{7} & \multirow{3}{*}{$\begin{array}{c}3 \text { days in a room } \\
\text { temperature then } 4 \\
\text { days fully immersed } \\
\text { in water }\end{array}$} \\
\hline & 6 & & \\
\hline & 10 & & \\
\hline \multicolumn{4}{|c|}{ Iled series } \\
\hline \multirow{3}{*}{$\begin{array}{l}\text { Mixtures with : } \\
\text { - Solitex } \\
\text { - Solitex A }\end{array}$} & 3 & \multirow{3}{*}{7} & \multirow{3}{*}{$\begin{array}{l}3 \text { days in a room } \\
\text { temperature then } \\
\text { freeze-thaw cycles } \\
\text { for } 4 \text { days }\end{array}$} \\
\hline & 6 & & \\
\hline & 10 & & \\
\hline
\end{tabular}

Table 3. CBR moisture content of the tested soils

\begin{tabular}{|c|c|c|}
\hline Soil & $\begin{array}{c}\text { Stabiliser addition } \\
{[\%]}\end{array}$ & $\begin{array}{c}\text { CBR moisture } \\
\text { content [\%] }\end{array}$ \\
\hline Clayey-sandy silt & - & 9.40 \\
\hline \multirow{2}{*}{$\begin{array}{c}\text { Mixture with } \\
\text { Solitex }\end{array}$} & 3 & 9.60 \\
\cline { 2 - 3 } & 6 & 10.70 \\
\hline \multirow{2}{*}{$\begin{array}{c}\text { Mixture with } \\
\text { Solitex A }\end{array}$} & 10 & 10.20 \\
\cline { 2 - 3 } & 3 & 10.60 \\
\cline { 2 - 3 } & 6 & 11.20 \\
\hline
\end{tabular}

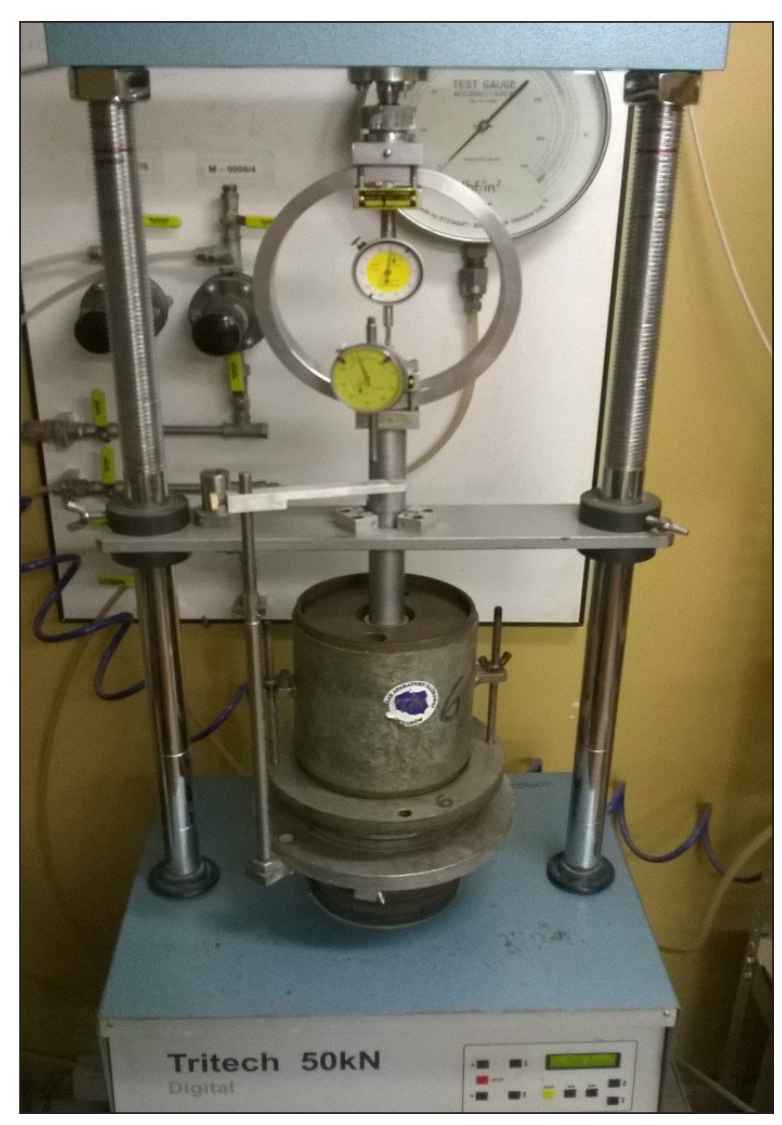

Figure 2. Tritech 50 press (laboratory of the Department of Hydraulic Engineering and Geotechnics)

\section{RESULTS AND DISCUSSION}

The results of bearing ratio tests of the silt are presented in Table 4. It can be noticed that directly after compaction the bearing ratio was higher $(22.6 \%-24.5 \%)$ than after four days of soaking in water $(14.9 \%-15.7 \%)$. It indicates high sensitivity of the soil to changes in moisture content.

Table 5 and Figures 3 and 4 present the values of the bearing ratio in relation to different methods of curing, time and percentage addition of the stabiliser.

The bearing ratio of the unstabilised soil had the lowest value in relation to the stabilized soil. In case of 3, 6 and $10 \%$ addition of the stabilizer the bearing ratio values increased several times.

The differences between the values of the bearing ratio of samples stabilized using Solitex and Solitex A increased along with the increase in binder addition and time of curing. In case of samples with 3\% addition of Solitex A directly after compaction at the load of 22 and $44 \mathrm{~N}$ the bearing ratio was 1.02 -times and 1.05-times higher than in case of $3 \%$ addition of Solitex. After 7 days of soaking in water these values were adequately 2.15-times and 2.33-times higher than the previous ones. After freeze-thaw cycles the bearing ratio of samples stabilised using Solitex A were adequately 1.8-times and 1.87-times higher than in case of Solitex.

Samples with $6 \%$ addition of Solitex A directly after compaction at the load of 22 and $44 \mathrm{~N}$ had the bearing ratio 1.07-times and 1.14-times higher than in case of Solitex addition. After 7-day curing, these values increased 3.4-times and 3.5-times in case of soaking in water and 1.3-times and 1.2-times in case of freeze-thaw cycles.

The bearing ratio of samples with $10 \%$ addition of Solitex A directly after compaction at the load of 22 and $44 \mathrm{~N}$ was 1.5-times higher than in case of Solitex addition. After 7-day curing these values increased 2.1-times and 2.3-times in case of soaking in water and 2-times and 2.1-times in case of freeze-thaw cycles.

Table 4. Bearing ratio of the clayey-sandy silt

\begin{tabular}{|c|c|c|}
\hline \multirow{2}{*}{$\begin{array}{c}\text { Load } \\
{[\mathrm{N}]}\end{array}$} & \multicolumn{2}{|c|}{ Bearing ratio CBR [\%] } \\
\cline { 2 - 3 } & $\begin{array}{c}\text { directly after } \\
\text { compaction }\end{array}$ & $\begin{array}{c}\text { after four days of } \\
\text { soaking in water }\end{array}$ \\
\hline 22 & 24.5 & 15.7 \\
\hline 44 & 22.6 & 14.9 \\
\hline
\end{tabular}


Table 5. Bearing ratio of the tested soils

\begin{tabular}{|c|c|c|c|c|c|c|c|}
\hline \multirow{4}{*}{$\begin{array}{l}\text { Soil with the } \\
\text { binder: }\end{array}$} & \multirow{4}{*}{$\begin{array}{c}\text { Addition } \\
\text { [\%] }\end{array}$} & \multicolumn{6}{|c|}{ Bearing ratio CBR [\%] } \\
\hline & & \multicolumn{6}{|c|}{ Time of curing [days]: } \\
\hline & & \multicolumn{2}{|c|}{ directly after compaction } & \multicolumn{2}{|c|}{ Ist series* } & \multicolumn{2}{|c|}{ Iled $^{\text {series* }}{ }^{*}$} \\
\hline & & $22 \mathrm{~N}$ & $44 \mathrm{~N}$ & $22 \mathrm{~N}$ & $44 \mathrm{~N}$ & $22 \mathrm{~N}$ & $44 \mathrm{~N}$ \\
\hline \multirow{3}{*}{ Solitex } & 3 & 25.3 & 27.5 & 24.1 & 21.8 & 12.6 & 11.4 \\
\hline & 6 & 29.7 & 26.9 & 33.4 & 31.0 & 26.7 & 24.4 \\
\hline & 10 & 31.3 & 33.0 & 64.6 & 60.5 & 43.4 & 43.3 \\
\hline \multirow{3}{*}{ Solitex A } & 3 & 25.7 & 28.8 & 51.8 & 50.9 & 22.8 & 21.3 \\
\hline & 6 & 31.7 & 30.7 & 113.9 & 109.6 & 34.9 & 29.3 \\
\hline & 10 & 48.5 & 48.4 & 135.4 & 136.8 & 86.9 & 91.1 \\
\hline
\end{tabular}

* see chapter materials and methods

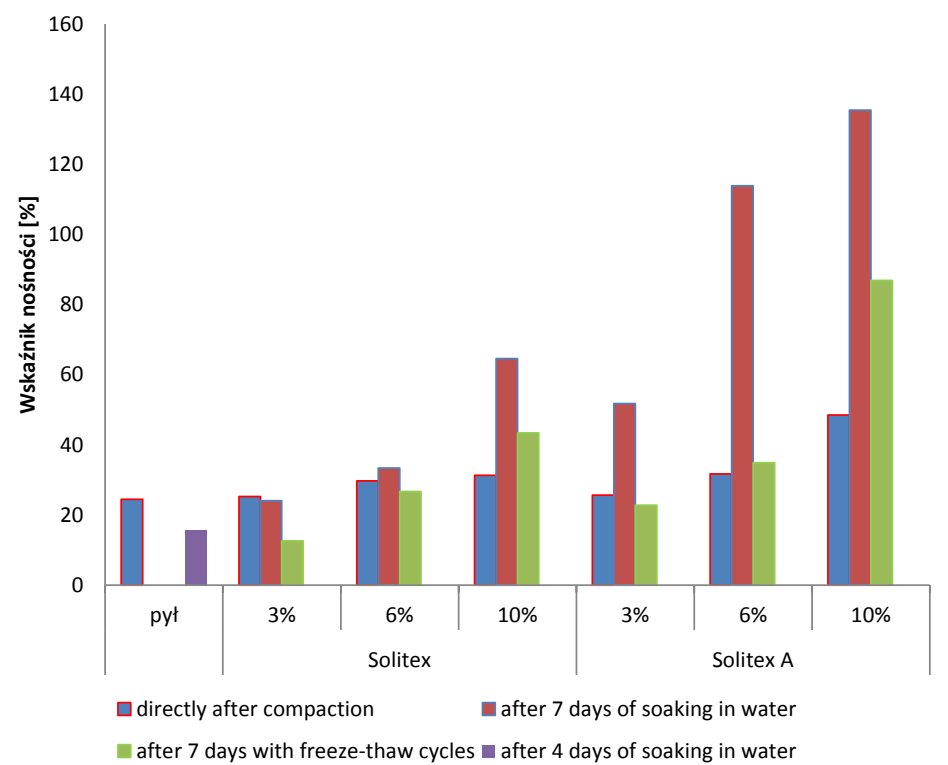

Figure 3. The bearing ratio of the tested samples in relation to the time of curing, type and addition of the binder at the load of $22 \mathrm{~N}$

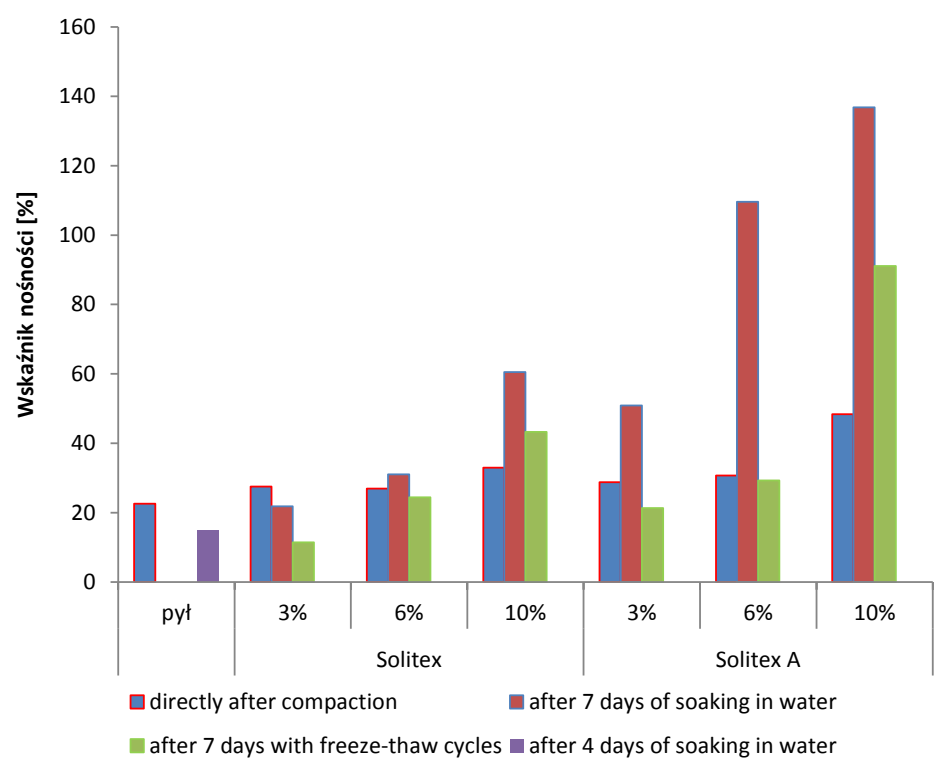

Figure 4. The bearing ratio of the tested samples in relation to the time of curing, type and addition of the binder at the load of $44 \mathrm{~N}$ 


\section{CONCLUSIONS}

Stabilisation of clayey-sandy silt using road binder SOLITEX and hydraulic binder SOLITEX A has positive effects because it improves its mechanical properties. The bearing ratio of the stabilised material is relatively high. The best binder is SOLITEX A, because the results with the addition of 3, 6 and $10 \%$ are much higher than with the same amount of SOLITEX. In each case the values of the bearing ratio tests after 7 days of soaking in water increased and after 7 days with freeze-thaw cycles these values decreased and usually they were lower than the previous ones.

\section{REFERENCES}

1. Attachment to the Resolution of the Council of Ministers of 2015. National roads development programme 2014-2023.

2. General Director for National Roads and Motorways. Catalogue of typical flexible and semi-rigid pavements (in Polish). Warsaw.

3. General Director for National Roads and Motorways. Catalogue of typical rigid pavements. Attachment to regulation No. 30 (in Polish). Warsaw.

4. General Director for National Roads and Motorways. Report on the technical condition of national road network at the end of 2014 (in Polish). Warsaw.
5. Material safety data sheet - binder for soil improving soils SOLITEX of September $8^{\text {th }}, 2014$.

6. Myślińska E. 1998. Laboratory tests of soils (in Polish). PWN, Warszawa, 37-46.

7. Pisarczyk S. 2014. Engineering soil science (in Polish). PWN, Warszawa, 135-137, 164-175.

8. PN-EN ISO 14668-2. Geotechnical tests. Geotechnical investigation and testing. Identification and classification of soil. Part 2. Principles for a classification (Polish standard).

9. PN-S-02205: 1998. Roads. Earthworks. Requirements and tests (Polish standard).

10. PN-S-96012: 1997. Roads. Subbase and improved ground from cement-stabilised soil (Polish standard).

11. Regulation of the Minister of Transport and the Maritime Economy on March $2^{\text {ed }} 1999$, on technical conditions which must be fulfilled by public roads (Journal of Laws 1999.43.430).

12. Szpikowski M. 2006. Tests and determination of preliminary relations for the evaluation of the bearing capacity of cohesive soils using dynamic CBR method. Vol. 2 (in Polish). Road and Bridge Research Institute. Warsaw.

13. Technical specification - instruction manual. Using road binders SOLITEX, 2013. EDF, Rybnik.

14. Wiłun Z. 2000. Geotechnics (in Polish). Wydawnictwo Komunikacji i Łączności, Warszawa, 550-553, 570-577. 